\title{
IODOMETRIC DETERMINATION OF CEFUROXIME BY THE POTASSIUM HYDROGENPEROXOMONOSULPHATE REACTION
}

\author{
Yu.Yu.Serdiukova, M.M.Ivashura, T.O.Oleksienko \\ National University of Pharmacy \\ Key words: cefuroxime; iodometric determination; potassium hydrogenperoxomonosulphate
}

\begin{abstract}
Simple methods for oxidimetric determination of antibiotic Cefuroxime in the substance and in the powder for solution for injection, which are based on the S-oxidation reaction by potassium hydrogenperoxomonosulphate in a weak acidic medium to S-oxide with the subsequent determination of the residual oxidising agent by the iodometric method, have been developed. A triple potassium salt of Caro's acid, $2 \mathrm{KHSO}_{5} \cdot \mathrm{KHSO}_{4} \cdot \mathrm{K}_{2} \mathrm{SO}_{4}$ was used as an oxidising agent. Quantitative oxidation of the Sulphur atom completes during the period that is less than $1 \mathrm{~min}$. The mean recovery of the active ingredient in the substance of cefuroxime was $98.67 \%, R S D=0.57 \%(\delta=0.33 \%)$. The mean recovery of the medicine "Cefuroxime", $750 \mathrm{mg}$, is $782.8 \mathrm{mg}, R S D=0.97 \%$ ( $\delta=0.91 \%$ ), which should be 680 $900 \mathrm{mg}$ calculated with reference to dried substance. The $L O Q$ is $C=0.05 \mathrm{mg} \mathrm{mL}^{-1}$. The advantages of the method proposed are the ability of analytical determination of cefuroxime by the biologically active part of the molecule, namely alicyclic Sulphur, good precision and accuracy of the results. The validation data obtained meet the requirements of the State Pharmacopoeia of Ukraine, they indicate the possibility of its introduction in the practice of analytical laboratories analysis, application during the stepwise control process of drug manufacturing or the quality control during equipment washing.
\end{abstract}

Cefuroxime (Cefuroxim), (6R,7R)-3-\{[(aminocarbonyl)oxy]methyl $\}-7-(\{(2 \mathrm{E})-2-$ furan-2-yl-2-[(methyloxy)imino]acetyl amino)-8-oxo-5-thia-1-azabicyclo [4.2.0]oct-2-ene-2-carboxylic acid, is a derivative of 7-ADCC and belongs to semisynthetic cephalosporin $\beta$-lactam antibiotics of the II generation. The $\mathrm{EPh}$ and $\mathrm{BP}$ recommend to determine cefuroxime using the method of HPLC $[3,6]$. The classical iodometric titration method is long lasting and unreliable [1]. The extensive literature survey reveals several procedures of cefuroxime determination in medicines using liquid chromatography [12], capillary electrophoresis [8], polarography [2], and spectrofluorimetry [9]. A lot of spectrophotometric $[4,5,11]$ and titrimetric $[10,7]$ methods for quantitative determination of cefuroxime have been developed.

The aim of the study was to develop a new method for quantitative determination of cefuroxime in the substance and the powder for solution for injection by oxidimetry using potassium hydrogenperoxomonosulphate as an analytical reagent $\left(\mathrm{KHSO}_{5}\right)$.

Materials and Methods

A triple potassium salt of Caro's acid, $2 \mathrm{KHSO}_{5} \cdot \mathrm{KHSO}_{4}{ }^{\circ}$ $\mathrm{K}_{2} \mathrm{SO}_{4}$ (the trade name - "Oxon ${ }^{\circledR) "}$ manufactured by DuPont), was used as an oxidising agent. The active substance is potassium hydrogenperoxomonosulphate, $\mathrm{KHSO}_{5}$. The choice of the reagent was determined by its rather high oxidative activity, $\mathrm{E}_{0}=1.84 \mathrm{~V}$, availability, and satisfactory solubility in water.
1. Potassium hydrogenperoxomonosulphate solution, $0.02 \mathrm{Mol} \mathrm{L}^{-1}$. Dissolve $0.615 \mathrm{~g}$ of $2 \mathrm{KHSO}_{5} \cdot \mathrm{KHSO}_{4} \cdot$ $\mathrm{K}_{2} \mathrm{SO}_{4}$ in $50 \mathrm{~mL}$ of distilled water in a $100 \mathrm{~mL}$ volumetric flask. Dilute the solution to the volume with water at $20^{\circ} \mathrm{C}$.

The content of $\mathrm{KHSO}_{5}$ in the solution prepared was determined by iodometric titration [3].

2. Sodium thiosulphate solution, $0.02 \mathrm{Mol} \mathrm{L}^{-1}$. Prepare $0.1 \mathrm{Mol} / \mathrm{L}^{-1}$ of the sodium thiosulphate solution from the standard titre fixanal. Pipette $20 \mathrm{~mL}$ of the solution obtained and transfer into a $100 \mathrm{~mL}$ volumetric flask. Dilute to the volume with water at $20^{\circ} \mathrm{C}$.

3. Potassium iodine solution, 5\%. Dissolve $5.0 \mathrm{~g}$ of the sample weight of potassium iodine in $50 \mathrm{~mL}$ of distilled water in a $100 \mathrm{~mL}$ volumetric flask. Dilute to the volume with water at $20^{\circ} \mathrm{C}$.

4. Sulphuric acid solution, $0.1 \mathrm{Mol} \mathrm{L}^{-1}$. Prepared from the standard titre fixanal in a $500 \mathrm{~mL}$ volumetric flask.

The method for studying the S-oxidation reaction kinetics. Pipette $10.0 \mathrm{~mL}$ of $0.02 \mathrm{Mol} \mathrm{L}^{-1}$ potassium hydrogenperoxomonosulphate solution, transfer in a $100 \mathrm{~mL}$ volumetric flask, add $10.0 \mathrm{~mL}$ of $0.01 \mathrm{Mol} / \mathrm{L}^{-1}$ cefuroxime solution and switch on a stop watch. Dilute to the volume with distilled water and mix thoroughly. At specific time intervals pipette $10 \mathrm{~mL}$ of the mixture obtained, transfer in a flask for titration, acidify with $1 \mathrm{~mL}$ of $0.1 \mathrm{Mol} / \mathrm{L}^{-1}$ sulphuric acid solution and add $1 \mathrm{~mL}$ of $5 \%$ 
potassium iodine solution. Titrate the iodine liberated with $0.02 \mathrm{Mol} / \mathrm{L}^{-1}$ of the titrated solution of sodium thiosulphate in the presence of starch.

The medicine Cefuroxime, powder for solution for injection, 0.75, manufactured by "Lekchim-Kharkov", the batch 10712230412 was used.

The titrant volume was measured using a $10 \mathrm{~mL}$ microburette with the accuracy of $\pm 0.01 \mathrm{~mL}$.

Assay for cefuroxime in the powder for preparing the solution for injection. Dissolve $0.43 \mathrm{~g}$ (accurate weight) of the powder of the medicine with the known moisture content $(w, \%)$ in $70 \mathrm{~mL}$ of distilled water and dilute the volume to $100.00 \mathrm{~mL}$. Transfer $10.00 \mathrm{~mL}$ into a $100 \mathrm{~mL}$ volumetric flask, add $10.00 \mathrm{~mL}$ of $0.02 \mathrm{Mol} / \mathrm{L}^{-1} \mathrm{KHSO}_{5}$ solution, dilute to the volume with distilled water, mix thoroughly and leave for $1 \mathrm{~min}$. Then transfer $10.00 \mathrm{~mL}$ of the solution obtained into a flask for titration, add $1 \mathrm{~mL}$ of $0.1 \mathrm{Mol} \mathrm{L}^{-1}$ sulphuric acid solution and $1 \mathrm{~mL}$ of $5 \%$ potassium iodine solution. Titrate the iodine liberated with $0.02 \mathrm{Mol} / \mathrm{L}^{-1}$ of sodium thiosulphate solution $(V, \mathrm{~mL})$.

Simultaneously the control experiment was carried out under similar condition (without cefuroxime with the same amount of $0.02 \mathrm{Mol} / \mathrm{L}^{-1}$ of $\mathrm{KHSO}_{5}$ solution $\left(V_{0}, \mathrm{~mL}\right)$.

The content of cefuroxime in the powder for solution for injection X $(\mathrm{g})$ was calculated by the formula:

$$
X=\frac{\left(V_{0}-V\right) \cdot K \cdot T \cdot \bar{m} \cdot 100 \cdot 100 \cdot 100}{2 \cdot m_{w} \cdot(100-w) \cdot 10 \cdot 10},
$$

where: $V_{0}-$ is the volume of the standard $0.02 \mathrm{Mol} / \mathrm{L}^{-1}$ sodium thiosulphate solution used for titration in the control experiment, $\mathrm{mL} ; V-$ is the volume of the standard $0.02 \mathrm{Mol} / \mathrm{L}^{-1}$ sodium thiosulphate solution used for titration in the experiment with cefuroxime, $\mathrm{mL} ; K-$ is the correlation coefficient of the concentration for the standard $0.0200 \mathrm{Mol} / \mathrm{L}^{-1}$ sodium thiosulphate solution; $T$ - is the cefuroxime weight corresponding to $1.00 \mathrm{~mL}$ of the standard $0.0200 \mathrm{Mol} / \mathrm{L}^{-1}$ sodium thiosulphate solution, $\mathrm{g} / \mathrm{mL}^{-1} ; 100$ and $10-$ are the volumes of the volumetric flask and aliquots of the solution taken for analysis, $\mathrm{mL}$; $m_{w}-$ is the sample weight, $\mathrm{g} ; \bar{m}-$ is the average weight of the vial, $\mathrm{g} ; w-$ is the moisture content in the medicine, $\%$.

$1.00 \mathrm{~mL}$ of the standard $0.0200 \mathrm{Mol} / \mathrm{L}^{-1}$ sodium thiosulphate solution correspond to $0.004244 \mathrm{~g}$ of cefuroxime $\left(\mathrm{C}_{16} \mathrm{H}_{16} \mathrm{~N}_{4} \mathrm{O}_{8} \mathrm{~S}\right)$, the medicine should contain $0.68-0.90 \mathrm{~g}$ calculated with reference to dried substance.

\section{Results and Discussion}

The peroxiacidic method proposed is based on the reaction of Cefuroxime oxidation by the excess of $\mathrm{KHSO}_{5}$ with quantitative formation of the corresponding S-oxide in the acidic medium. The $\mathrm{KHSO}_{5}$ excess was determined by the method of iodometric tirtation.

It has been determined that the redox interaction between cefuroxime and potassium hydrogenperoxomonosulphate occurs quantitatively and stoichiometrically: $1 \mathrm{Mol}$ of $\mathrm{KHSO}_{5}$ per $1 \mathrm{Mol}$ of the medicine.

Quantitative oxidation of the Sulphur atom completed during the period that did not exceed 1 min by the method of iodometric titration.

The scheme of the S-oxidation reaction of cefuroxime using potassium hydrogenperoxomonosulphate is given in Fig.<smiles>[R]NC1C(=O)N2C(C(=O)O[Na])=CCS[C@H]12</smiles><smiles>[R19]C1C(=O)N2C(C(=O)O[Na])=CCS(=O)C12</smiles><smiles>[R]=[R]1ccc(C(=NOC)C(C)=O)o1</smiles>

Fig. The scheme of the S-oxidation reaction of cefuroxime using potassium hydrogenperoxomonosulphate.

Table

The results of quantitative determination of cefuroxime in the substance and in the powder for solution for injection $(\mathrm{P}=0.95)$

\begin{tabular}{|c|c|c|}
\hline Taken & Found & Metrological characteristics \\
\hline \multicolumn{3}{|c|}{ Cefuroxime substance, $\%$} \\
\hline $99.00 \%$ & $\begin{array}{l}99.10 \\
99.10 \\
99.10 \\
98.07 \\
98.07\end{array}$ & $\begin{array}{c}\bar{x}=98.67 \\
S=0.57 \\
S_{\bar{x}}=0.253 \\
\Delta \bar{x}=0.703 \\
R S D=0.57 \% \\
\varepsilon=0.71 \% \\
\delta=-0.33 \%\end{array}$ \\
\hline \multicolumn{3}{|c|}{ Cefuroxime, powder for solution for injection, $0.75 \mathrm{~g}$} \\
\hline 0.7900 & $\begin{array}{l}0.7705 \\
0.7705 \\
0.7869 \\
0.7869 \\
0.7869 \\
0.7869 \\
0.7869 \\
0.7869\end{array}$ & $\begin{array}{c}\bar{x}=0.7828 \\
S=0.0759 \\
S_{\bar{x}}=0.0027 \\
\Delta \bar{x}=0.0064 \\
R S D=0.97 \% \\
\varepsilon=0.82 \% \\
\delta=0.91 \%\end{array}$ \\
\hline
\end{tabular}

* The content of the active substance was determined by the HPLC method given in the certificate.

The results of quantitative determination of cefuroxime in the substance and in the medicine are given in Table. They show that the methods developed allow to determine the content of cefuroxime in the substance and the powder for solution for injection, $0.75 \mathrm{~g}, \mathrm{RSD}=$ $0.57 \div 0.97 \%, \delta=0.3 \div 0.91 \%$.

The Limit of Quantification (LOQ) is $0.05 \mathrm{mg} \mathrm{mL}^{-1}$.

The advantages of the method proposed are the ability of analytical determination of cefuroxime by the biologically active part of the molecule, namely alicyclic Sulphur, good precision and accuracy of the results. It does not require the use of expensive reference standards, toxic solvents and special equipment as in the HPLC method. It is simple and rapid in application.

\section{CONCLUSIONS}

It has been proposed to use potassium hydrogenperoxomonosulphate as an analytical reagent for cefuroxime.

The methods for oxidimetric determination of the active ingredient in the substance and in Cefuroxime, powder for solution for injection, $0.75 \mathrm{~g}$, which are based on the $\mathrm{S}$-oxidation reaction by potassium hydrogen- 
peroxomonosulphate in the acidic medium to the corresponding S-oxide with the subsequent determination of the residual oxidising agent by the iodometric method, have been proposed and developed $(\mathrm{RSD}=0.57 \div 0.97 \%$, $\delta=0.3 \div 0.91 \%$ ). The Limit of Quantification (LOQ) is $0.05 \mathrm{mg} \mathrm{mL}^{-1}$.

\section{REFERENCES}

1. Арзамасиев А.П. Фармачевтическая химия: Учеб. пособ. / Под ред. А.П.Арзамасиев. - М.: ГЭОТАР-МЕД, 2004. - 640 c.

2. Bernacca G., Nucci L., Pergola F. // Electroanal. - 1994. - Vol. 6, №4. - P. 327-332.

3. British Pharmacopoeia. - London: The Stationery Office, 2009. - 10952 p.

4. Chaudari S.V., Karnik A., Adhikary A. et al. // Ind. J. Pharm. Sci. - 2006. - Vol. 6, №1. - P. 59-63.

5. El-Gindy A1., El-Walily A.F., Bedair M.F. // J. Pharm. Biomed. Anal. - 2000. - Vol. 23, №2-3. - P. 341-352.

6. European Pharmacopoeia. Vol. 1-2 / European Directorate for the Quality of Medicines \& Health Care. - 7th ed. Strassbourg: - Council of Europe, 2010. - 3536 p.

7. Helaleh M.I.H., Abu-Named E.S.M., Jamhour R.M.A.Q. // Acta Pol. Pharm. Drug Res. - 1998. - Vol. 55, №2. - P. 93-97.

8. Mrestani Y., Neubert R.H., Härtl A. et al. // Anal. Chim. Acta. - 1997. - Vol. 349. - P. 207-213.

9. Murillo J.A., Lemus J.M., Garcia L.F. // J. Pharm. Biomed. Analysis. - 1994. - Vol. 12, №7. - P. 875-881.

10. Pospisilova B., Kubes J. // Pharmazie. - 1998. - Vol. 43, №4. - P. 246-248.

11. Rezowanur R.M., Asaduzzaman M., Ashraful S.M. // Am. J. Pharm. Tech. Res. - 2012. - Vol. 2, №4. - P. 351-358.

12. Shaha N.J., Shaha S.K., Patel V.F. et al. // Ind. J. Pharm. Sci. - 2007. - Vol. 69, №1. - P. 140-142.

\section{ЙОДОМЕТРИЧНЕ ВИЗНАЧЕННЯ ЦЕФУРОКСИМУ ЗА РЕАКЦІЄЮ 3 КАЛІЮ ГІДРОПЕРОКСОМОНОСУЛЬФАТОМ \\ Ю.Ю.Сердюкова, М.М.Івашура, Т.О.Олексієнко}

Ключові слова: цефуроксим; йодометричне титрування; калію гідропероксомоносульфат Розроблені прості методики оксидиметричного визначення цефуроксиму у субстанції та у порошку для приготування ін'єкцій, засновані на реакції кількісного окиснення цефуроксиму калію гідропероксомоносульфратом у кислому середовищі до відповідного S-оксиду з наступним визначенням залишку окисника йодометричним методом. Як окисник використовували потрійну калійну сіль кислоти Каро $2 \mathrm{KHSO}_{5} \cdot \mathrm{KHSO}_{4} \cdot \mathrm{K}_{2} \mathrm{SO}_{4}$. Кількісне окиснення атома сульфруру з утворенням відповідного сульфооксиду цефралоспорину завершувалось за час, що не перевищував 1 хв. Вміст основної речовини у субстанції цесруроксиму становив $98,67 \% R S D=0,57 \%$ ( $\delta=0,33 \%)$. У лікарському препараті «Цесруроксим» по 750 мг - 782, 8 ме, RSD = 0,97\% ( $\delta=0,91 \%$ ), якого в препараті має бути 680-900 мг у перерахунку на безводну речовину. Нижня межа визначуваних концентрацій - $C_{\text {н }}=0,05$ мг/мл. Перевагами запропонованого способу виконання аналізу є можливість здійснення аналітичного визначення цефруроксиму за біологічно активною частиною молекули, а саме за аліциклічним сульфуром, а також задовільна відтворюваність та правильність результатів. Одержані валідаційні характеристики відповідають критеріям прийнятності заідно з ДФУ, що свідчить про можливість їх впровадження в практику аналізу контрольно-аналітичних лабораторій або використання під час здійснення постадійного контролю процесу виготовлення лікарських засобів чи контролю якості відмивки обладнання.

\section{ЙОДОМЕТРИЧЕСКОЕ ОПРЕДЕЛЕНИЕ ЦЕФУРОКСИМА ПО РЕАКЦИИ С ГИДРОПЕРОКСОМОНОСУЛЬФАТОМ КАЛИЯ Ю.Ю.Сердюкова, М.Н.Ивашура, Т.А.Алексеенко}

Ключевые слова: цефруроксим; йодометрическое титрование; гидропероксомоносульфрат калия Разработаны простые методики оксидиметрического определения цефуроксима в субстанции и порошке для приготовления инъекций, которые основаны на реакции количественного окисления цефуроксима гидропероксомоносульфратом калия в кислой среде до соответствующего S-оксида с последующим определением остатка окислителя йодометрическим методом. Как окислитель использовали тройную калиевую соль кислоты Каро $2 \mathrm{KHSO}_{5} \cdot \mathrm{KHSO}_{4} \cdot \mathrm{K}_{2} \mathrm{SO}_{4}$. Количественное окисление атома серы с образованием соответствующего сульфроксида цефралоспорина заканчивается за время, котрое не превышало 1 мин. Содержание основного вещества в субстанции цесруроксима составляло 98,67\%, RSD =0,57\% ( $\delta=0,33 \%)$. В лекарственном препарате «Цефруроксим» по 750 мг - 782,8 м2, RSD = 0,97\% ( $\delta=0,91 \%)$, которого в препарате должно быть 680-900 мг в пересчете на безводное вещество. Предел количественного определения $-C_{н}=0,05$ мг/мл. Преимуществами предложенного способа выполнения анализа является возможность осуществления аналитического определения цесруроксима по биологически активной части молекулы, а именно по алициклической сере, а также удовлетворительная воспроизводимость и правильность результатов. Полученные валидационные характеристики соответствуют критериям приемлемости согласно ГФУ, которые свидетельствуют о возможности внедрения ее в практику анализа контрольно-аналитических лабораторий или использования во время осуществления постадийного контроля процесса приготовления лекарственных средств, или контроля качества отмывки оборудования. 